\title{
L-carnitine supplementation in the recovery of plasma L-carnitine in patients with heart failure submitted to coronary artery bypass grafting
}

\author{
WANISE M. SOUZA CRUZ ${ }^{1,3}$, SHEILA M.S. GUIMARÃES ${ }^{2}$, GABRIELLE C. MACIEL ${ }^{2}$, ANA BEATRIZ \\ A. HUGUENIN ${ }^{2}$, MONICQUE E.M. DE CARVALHO ${ }^{2}$, BÁRBARA O. COSTA ${ }^{2}$, GEISIANE A. DA SILVA ${ }^{2}$ \\ ALEXANDRE S. COLAFRANCESCHI ${ }^{4}$, FERNANDA B. SCALCO ${ }^{3}$ and MARCIA RIBEIRO ${ }^{1}$
}

\author{
${ }^{1}$ Departamento de Pediatria, Faculdade de Medicina, Universidade Federal do Rio de Janeiro, Rua \\ Bruno Lobo, 50, Cidade Universitária, Ilha do Fundão, 21044-020 Rio de Janeiro, RJ, Brazil \\ ${ }^{2}$ Laboratório de Nutrição Experimental, Departamento de Nutrição e Dietética, Faculdade de Nutrição, Universidade \\ Federal Fluminense, Rua Mário Santos Braga, 30, Campus do Valonguinho, Centro, 24020-140 Niterói, RJ, Brazil \\ ${ }^{3}$ Laboratório de Erros Inatos do Metabolismo/LABEIM, Instituto de Química, Universidade \\ Federal do Rio de Janeiro, Departamento de Bioquímica, Avenida Horácio Macedo, 1281, Bloco \\ C, Polo de Química, Cidade Universitária, 21941-598 Rio de Janeiro, RJ, Brazil \\ ${ }^{4}$ Instituto Nacional de Cardiologia, Departamento de Cirurgia, Rua das Laranjeiras, \\ 374, Laranjeiras, 22240-006 Rio de Janeiro, RJ, Brazil
}

Manuscript received on May 17, 2017; accepted for publication on November 16, 2017

\begin{abstract}
Coronary artery bypass grafting reduces plasma L-carnitine and may impair the production of myocardial energy. L-carnitine supplementation may elevate plasma L-carnitine and increase cardiac mechanical efficiency. The objective of this study was to verify the recovery of preoperative plasma LC in patients with heart failure undergoing coronary artery bypass grafting supplemented with a daily oral dose of $50 \mathrm{mg}$ $/ \mathrm{kg}$. Volunteers with ischemic heart failure who underwent surgery were randomized into a supplemented group (A-received $50 \mathrm{mg} / \mathrm{kg}$ L-carnitine) or placebo group (B) for 60 days. Supplementation was started on the third postoperative day. The spectrophotometric enzymatic method was used to quantify plasma L-carnitine. In the preoperative period, both groups had plasma L-carnitine adequate to the reference range (18.9-71.1 $\mu \mathrm{M})$. On the second postoperative day, there was a reduction in plasma L-carnitine in groups $\mathrm{A}(17.4 \%)$ and $\mathrm{B}(14.4 \%)$. In the comparison between the groups, plasma L-carnitine was higher in group A than $B$ in $10^{\circ}(p=0.024), 30^{\circ}(p=0.001)$, and $60^{\circ}$ postoperative day $(\mathrm{p}=0.008)$. Supplementation of L-carnitine at a daily oral dose of $50 \mathrm{mg} / \mathrm{kg}$ in patients with heart failure undergoing coronary artery bypass grafting may recover preoperative plasma L-carnitine within 10 days.
\end{abstract}

Key words: ischemic heart failure, myocardial revascularization surgery, oral L-carnitine supplementation, plasma L-carnitine.

Correspondence to: Wanise Maria de Souza Cruz

E-mail: wanisecruz@gmail.com 


\section{INTRODUCTION}

Of all the human organs, the heart has the greatest expenditure of energy at rest, and therefore has a high demand for energy to sustain its workload. Under physiological conditions, with an adequate supply of oxygen, the heart preferably uses betaoxidation of fatty acids (FA) to generate energy. L-carnitine (LC) is a nutrient that plays an important role in the transport of FA to mitochondria and theirs consequent oxidation. In addition, LC acts in the removal of mitochondrial metabolism products (Silvério et al. 2009). In heart failure (HF), the heart becomes unable to provide oxygen and nutrients to meet the needs of the body. The available evidence suggests that a reduction of cardiac bioenergetics may be determinant in the development of HF (Wong et al. 2016). In ischemic HF, oxygen supply is decreased and myocardial revascularization is a treatment that aims to increase myocardial perfusion (Ziabakhsh-Tabary et al. 2014). In a single study published by Da Silva Guimarães et al. (2013), the authors showed that plasma LC was reduced after surgical revascularization. Low plasma LC can facilitate oxidative stress and, reduce energy production, compromising mechanical efficiency of the heart (Dantas et al. 2015). LC supplementation can be a strategy to recover and maintain adequate plasma LC. Despite the numerous clinical studies showing the benefit of supplementation in ischemic HF (Dinicolantonio et al. 2013, Soukoulis et al. 2009) there is still no recommendation of dosage and time of administration. Human studies used doses ranging from 2 to $6 \mathrm{~g}$ day for periods of days to weeks or months (Iliceto et al. 1995, Cruciani et al. 2006). We decided to test a daily oral dose of $50 \mathrm{mg} / \mathrm{kg}$. The objective of this study was to verify the recovery of preoperative plasma LC in patients with heart failure submitted to coronary artery bypass grafting supplemented with daily oral dose of $50 \mathrm{mg} / \mathrm{kg}$.

\section{METHODS}

This is a randomized, double blinded, placebocontrolled study. Volunteers with ischemic heart failure indicated for myocardial revascularization surgery were recruited at the National Institute of Cardiology / RJ between July 2012 and March 2014. Inclusion criteria were left ventricle ejection fraction $(\mathrm{LVEF}) \leq 50 \%$, myocardial viability and clinical and hemodynamic stability. Participants with liver or renal diseases or receiving L-carnitine supplement or with disabsorptive syndromes were excluded. Participants developing stroke, sepsis, prolonged hemodynamic shock and those who stopped using the supplement after surgery were also excluded. Participants were randomly placed in two groups using Excel ${ }^{\circledR}$ Microsoft $\AA$ : LC supplemented group, which received daily oral dose of $50 \mathrm{mg} / \mathrm{kg}$ (Group A), or a control group (Group B), which received a placebo. The trial lasted for 60 days. The choice of daily oral dose was based on the results obtained by Iliceto et al. (1995), who administered a daily oral dose of $6 \mathrm{~g}$ for 12 months without observing any adverse effects. Today the United States Food and Drug Administration (FDA) consider that LC supplementation in many disorders is safe (El-Hattab and Scaglia 2015).

All patients were on the use of angiotensin converting enzyme inhibitors, beta blockers, angiotensin receptor blockers and diuretics during the study. Oral supplementation was started three days after surgery.

To determine the plasma LC, $10 \mathrm{~mL}$ of blood was withdrawn from each participant under fasted conditions and measured by the spectrophotometric enzyme method (Indyk and Woolard 1995) standardized by the Laboratory of Inborn Errors of Metabolism of the Federal University of Rio de Janeiro. The reference range was established between 18.9 to $71.1 \mu \mathrm{M}$. Blood samples were collected in the pre and postoperative periods $\left(2^{\text {nd }}\right.$, 
$10^{\text {th }}, 30^{\text {th }}$ and $60^{\text {th }}$ days) for comparison between the groups.

The study was approved by the Ethics Committee of the Federal University of Fluminense (CAAE: 00612812.0.0000.5243) and conducted according to the Declaration of Helsinki. All participants signed the Informed Consent Term. The study was registered in the Brazilian Registry of Clinical Trials (RBR-7376mq).

Data were analyzed using SPSS software V.10 (SPSS Inc.), PASW v.18 (IBM) and Microsoft Excel. The normality of the data was verified by the Shapiro-Wilk test. The groups were compared in the periods studied using Student's t-test and Mann-Whitney, if applicable. The differences were considered significant at $\mathrm{p}<0.05$.

\section{RESULTS}

From July 2012 to March 2014, 46 patients were recruited and followed up. Six patients died, two had liver disease and one renal disease, three developed sepsis, two had hemodynamic shock and four were lost at follow-up. The remaining 28 participants completed the study. The demographic and clinical characteristics of the participants, prior to surgery, are presented in Table I.

The minimum and maximum total daily oral doses of LC supplemented were 3 and $4.8 \mathrm{~g}$, respectively. Mean plasma LC of both groups, in the evaluated periods, are presented in Figure 1. Considering the reference range used (18.9 - 71.1 $\mu \mathrm{M}$ ), adequate plasma LC were found in both groups in the preoperative period. In the comparison between the groups, on the second postoperative day of myocardial revascularization there was a reduction in plasma L-carnitine in groups $\mathrm{A}(17.4 \%)$ and $\mathrm{B}(14.4 \%)$, with no statistical difference $(\mathrm{p}=$ 0.798). Plasma L-carnitine was higher in group $A$ than $B$ in $10^{\circ}(\mathrm{p}=0.024), 30^{\circ}(\mathrm{p}=0.001)$, and $60^{\circ}$ postoperative days $(\mathrm{p}=0.008)$. It was observed

TABLE I

Baseline characteristics.

\begin{tabular}{|c|c|c|c|}
\hline & $\mathrm{n}(\%)$ & $\begin{array}{l}\text { Group A } \\
n=19(\%)\end{array}$ & $\begin{array}{l}\text { Group B } \\
n=9(\%)\end{array}$ \\
\hline Age $^{a}$ & $58.1 \pm 10.5$ & $60.9 \pm 9.8$ & $55.1 \pm 10.9$ \\
\hline Male & $26(92.9)$ & $17(89.5)$ & $9(100)$ \\
\hline Body Mass Index (BMI) ${ }^{\mathrm{ab}}$ & $27.9 \pm 4.1$ & $28.4 \pm 3.8$ & $27.4 \pm 4.6$ \\
\hline \multicolumn{4}{|l|}{ NYHA Class } \\
\hline II & $16(57.1)$ & $9(56.3)$ & $7(43.8)$ \\
\hline III & $12(42.9)$ & $5(41.7)$ & $7(58.3)$ \\
\hline $\operatorname{LVEF}(\%)^{\mathrm{a}}$ & $39.4 \pm 12.0$ & $38.8 \pm 12.6$ & $40.7 \pm 10.6$ \\
\hline \multicolumn{4}{|c|}{ Comorbidities } \\
\hline Hypertension $^{c}$ & $26(92.9)$ & $18(94.7)$ & $8(88.9)$ \\
\hline Type 2 Diabetes $^{\mathrm{d}}$ & $13(46.4)$ & $6(31.6)$ & $7(77.8)$ \\
\hline Dyslipidemia $^{e}$ & $28(100)$ & $19(100)$ & $9(100)$ \\
\hline Previous myocardial infarction & $19(67.9)$ & $12(63.1)$ & $7(77.8)$ \\
\hline
\end{tabular}

${ }^{\mathrm{a}}$ Mean \pm standard deviation.

${ }^{\mathrm{b}}$ BMI: Normal reference range 18.5 e $24.99 \mathrm{Kg} / \mathrm{m}^{2}$ (de Onis and Habicht 1996).

${ }^{\mathrm{c}}$ Resting blood pressure $>139 / 90 \mathrm{mmHg}$ (Sociedade Brasileira de Cardiologia 2010).

${ }^{\mathrm{d}}$ Fasting blood glucose $>126 \mathrm{mg} / \mathrm{dL}$ (Sociedade Brasileira de Diabetes 2015).

${ }^{\mathrm{e}}$ Total cholesterol $>239 \mathrm{mg} / \mathrm{dL}$ and Triglycerides $<150 \mathrm{mg} / \mathrm{dL}$ (Sposito et al. 2007).

LVEF - Left Ventricular Ejection Fraction $>50 \%$ Teichholz Method.

Group A = Supplemented Group B = Placebo. 


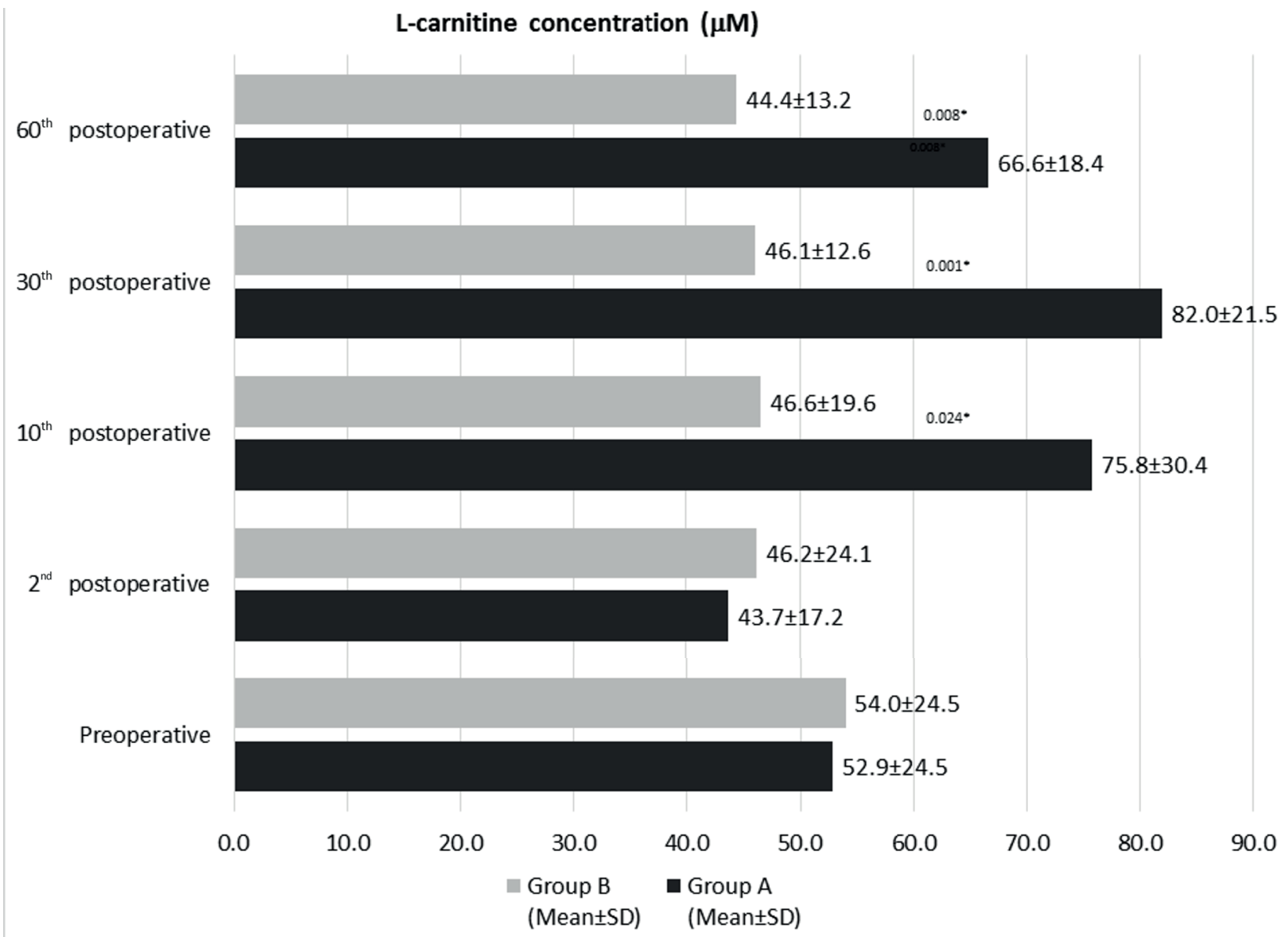

Figure 1 - Plasma concentrations of L-carnitine in all evaluated periods.

Results were presented as Mean and Standard Deviation (SD). Significance of differences: $\mathrm{p}<0.05^{*}$ compared A with B groups.

that group B did not recover the value found in the preoperative period.

\section{DISCUSSION}

Plasma LC deficiency was not observed in the present study, although patients with HF may be deficient in nutrients important for cardiac metabolism, such as LC, coenzyme Q10, creatine, taurine and thiamine (Wong et al. 2016).

Surgical revascularization can improve myocardial perfusion but it may also cause increased production of free radicals and systemic inflammatory stimuli (Hatemi et al. 2016). These side effects may be responsible for the reduction of plasma LC observed after surgery. Similar results were found by Da Silva Guimarães et al. (2013) and Nemoto et al. (2004). L-carnitine is considered a conditionally essential nutrient because in certain critical metabolic situations its plasma concentrations are reduced (Bonafe et al. 2014).

In this study, LC supplementation at the daily oral dose of $50 \mathrm{mg} / \mathrm{kg}$ was initiated on the third postoperative day. An increase in plasma LC was observed in the supplemented group on the $10^{\text {th }}$ day, $30^{\text {th }}$ day and was maintained until the $60^{\text {th }}$ postoperative day. This increase was expected due to supplementation with L-carnitine. The observed high plasma LC values may have been the result of continuous daily supplementation. This suggests that the metabolic requirement may have been exceeded. Physiologically, L-carnitine homeostasis is maintained by the balance between oral ingestion, 
endogenous synthesis, tissue saturation and renal excretion (El-Hattab and Scaglia 2015). According to Evans and Fornasini (2003), the renal absorption threshold decreases when the plasma LC exceeds $60 \mu \mathrm{M}$. Vaz et al. (2002) demonstrated that in the presence of a high oral intake of LC and adequate saturation of tissues, there is a reduction in the efficiency of renal resorption.

There are some limitations of this study that should be mentioned. First, the high loss of followup, resulting in a small number of participants who completed the study. Second, this study did not evaluate the urinary L-carnitine required to confirm that the renal threshold was exceeded.

\section{CONCLUSIONS}

The supplementation of L-carnitine at a daily oral dose of $50 \mathrm{mg} / \mathrm{kg}$ in patients with heart failure undergoing myocardial revascularization regains preoperative plasma LC in 10 days. Supplementation may be advantageous for patients with ischemic heart failure in removing toxic mitochondrial products and restoring cardiac energy metabolism, improving cardiac efficiency. This study opens up hypotheses for further studies of dose and time of supplementation.

\section{ACKNOWLEDGMENTS}

The authors would like to thank the study volunteers.

\section{REFERENCES}

BONAFE L, BERGER MM, QUE YA AND MECHANICK JI. 2014. Carnitine deficiency in chronic critical illness. Curr Opin Clin Nutr Metab Care 17: 200-209.

CRUCIANI RA ET AL. 2006. Safety, tolerability and symptom outcomes associated with L-carnitine supplementation in patients with cancer, fatigue, and carnitine deficiency: a phase I/II study. J Pain Symptom Manage 32(6): 551-559.

DA SILVA GUIMARÃES SMS, SAT'ANNA BC, DA COSTA CA, DE SOUZA CRUZ WM, COLAFRANCESCH AS AND BOAVENTURA GT. 2013. Assessments of free carnitine levels in the plasma of patients who have undergone coronary artery bypass grafting. Eur J Clin Nutr 67: 1334-1335.

DANTAS F ET AL. 2015. Potential Effect of L-Carnitine on the Prevention of Myocardial Injury after Coronary Artery Bypass Graft Surgery. J Tehran Heart Cent 10: 74-79.

DE ONIS M AND HABICHT JP. 1996. Anthropometric reference data for international use: recommendations from a World Health Organization Expert Committee. Am J Clin Nutr 64(4): 650-658.

DINICOLANTONIO JJ, LAVIE CJ, FARES H, MENEZES AR AND O'KEFFE JH. 2013. L-carnitine in the secondary prevention of cardiovascular disease: systematic review and meta-analysis. Mayo Clin Proc 88: 544-551.

EL-HATTAB AW AND SCAGLIA F. 2015. Disorders of carnitine biosynthesis and transport. Mol genet metab 116: 107-112.

EVANS AM AND FORNASINI G. 2003. Pharmacokinetics of L-carnitine. Clin Pharmacokinet 42: 941-967.

HATEMI AC, ÇEVIKER K, TONGUT A, ÖZGÖL İ, MERT M AND KAYA A. 2016. Oxidant Status following Cardiac Surgery with Phosphorylcholine-Coated Extracorporeal Circulation Systems. Oxid Med Cell Longev 2016: 1-10.

ILICETO S ET AL. 1995. Effects of L-carnitine administration on left ventricular remodeling after acute anterior myocardial infarction: the L-Carnitine Ecocardiografia Digitalizzata Infarto Miocardico (CEDIM) Trial. J Am Coll Cardiol 26: 380-387.

INDYK HE AND WOOLARD DC. 1995. Enzymatic determination of free carnitine in milk and infant formulas. J AOAC Int 78: 69-74.

NEMOTO S, YASUHARA K, NAKAMURA K, MIYOSHI Y AND SAKAI A. 2004. Plasma carnitine concentrations in patients undergoing open heart surgery. Ann Thorac Cardiovasc Surg 10: 19-22.

SILVÉRIO R, CAPERUTO EC AND SEELAENDER MC. 2009. L-carnitina: além do metabolismo de lipídios. Rev Mackenzie Ed F Esp 8: 135-145.

SOCIEDADE BRASILEIRA DE CARDIOLOGIA, SOCIEDADE BRASILEIRA DE HIPERTENSÃO, SOCIEDADE BRASILEIRA DE NEFROLOGIA. 2010. VI Diretrizes Brasileiras de Hipertensão. Arq Bras Cardiol 95(1 Suppl.1): 1-57.

SOCIEDADE BRASILEIRA DE DIABETES. 2015. Diretrizes da Sociedade Brasileira de Diabetes: 20142015. Organização José Egidio Paulo de Oliveira, Sérgio Vencio. São Paulo: AC Farmacêutica.

SOUKOULIS V ET AL. 2009. Micronutrient deficiencies an unmet need in heart failure. J Am Coll Cardiol 54: 16601673.

SPOSITO AC ET AL. 2007. IV Brazilian Guideline for Dyslipidemia and Atherosclerosis prevention: Department of Atherosclerosis of Brazilian Society of Cardiology. Arq Bras Cardiol 88 (Suppl. 1): 2-19. 
VAZ FM ET AL. 2002. Analysis of carnitine biosynthesis metabolites in urine by HPLC-electrospray tandem mass spectrometry. Clin Chem 48: 826-834.

WONG AP, NIEDZWIECKI A AND RATH M. 2016. Myocardial energetics and the role of micronutrients in heart failure: a critical review. Am J Cardiovasc Dis 6: 81-92.
ZIABAKHSH-TABARY S, JALALIAN R, MOKHTARIESBUIE F AND HABIBI MR. 2014. Echocardiographic Evaluation of the Effects of a Single Bolus of Erythropoietin on Reducing Ischemia-Reperfusion Injuries during Coronary Artery Bypass Graft Surgery; A Randomized, Double-Blind, Placebo-Control Study. Iran J Med Sci 39: 94-101. 